\title{
The Social Differentiation of the Polish Language of the Upper Silesia in the Second Half of the $19^{\text {th }}$ Century*
}

Key words: Upper Silesia, Polish language, Silesian dialect

The $19^{\text {th }}$ century was the period of deep transformations in the social structure of the Upper Silesia. The abolition of serfdom and the rapid development of industry triggered a long-lasting process of people's migration, the rise in urban populations, and the establishment of new industrial settlements. A considerably rapid increase in the number of inhabitants was noted in the Bytom district, which until 1873 also included the areas of Mysłowice, Katowice, Zabrze, and Tarnowskie Góry. ${ }^{1}$ The average density of population in this area since the beginning until the middle of the $19^{\text {th }}$ century had increased more than three-fold (MichatKIEWICZ, ed., 1970: 90), and in years 1850-1890 it multiplied manifold in the most industrialised region. Apart from Bytom, Tarnowskie Góry, and Mysłowice, which were the largest urban population centres in this area, new big industrial settlements developed in the second half of the $19^{\text {th }}$ century. Two of them, namely Katowice and Królewska Huta, were granted the city charter, and in 1890 they had 16,500 and 36,500 inhabitants, respectively. Other industrial communes, like Lipiny, Siemianowice, Zabrze, and Stare Zabrze, had around 10,000 inhabitants each. The population of Gliwice and its adjacent settlements was also increasing rapidly. This resulted in there coming into being - in the area of districts of Bytom, Katowice, Zabrze, Tarnowskie Góry, and Gliwice - of the biggest urban agglomeration in the Upper Silesia, an agglomeration of a specific vocational and social structure. A relatively small number of towns which constituted versatile and developed economic and cultural centres as well as a non-dynamic development of commerce, services, and institutions of culture in the majority of newlyestablished industrial settlements caused the vocational structure of the population of the Upper Silesian Industrial District to be rather poorly diversified. Along with places with long urban traditions, like Bytom, Gliwice, Mysłowice, and Tarnowskie Góry, it is solely Katowice that had a distinctly diversified social-vocational structure of its population, stemming from the economic multifunctionality of the city. The outskirts of Bytom and Katowice - as well as industrial settlements neighbouring them - were inhabited mainly

* Translation of the article entitled Zróżnicowanie socjalne polszczyzny górnośląskiej w drugiej połowie XIX wieku, first published in: „Socjolingwistyka” 1982, IV, pp. 141-152.

1 In 1873 the Bytom district was divided into four districts: the Bytom district, the Katowice district, the district of Tarnowskie Góry, and the Zabrze district. 
by the workers of big industrial plants. In big settlements, industry provided work to three-fourths up to four-fifths of the population (MICHAtKIEWICZ, ed., 1976: 33).

Together with industrial development, the character of the Upper Silesian villages was also changing. As early as in the mid-19 $9^{\text {th }}$ century, rural stratification and differentiation were more visible in industrialised areas than in agricultural districts. Towards the end of the $19^{\text {th }}$ century, the inhabitants of Upper Silesian villages were more and more often working outside of agriculture. The countryside was ceasing to represent strictly farming-oriented activities, and was frequently losing its old character (MICHAtKIEWICZ, ed., 1976: 197).

Dynamic industrialisation of the Upper Silesia also led to certain changes in the ethnic structure of its inhabitants. Even though those who came to towns and industrial settlements were migrants from Upper Silesian villages (that is, Poles), among industrialists, technical supervision and administration workers, as well as among more affluent merchants and craftsmen prevailed Germans. The number of German people was rising together with the development and modernisation of industrial plants, to which professionals were brought from inland Germany. In towns, the percentage of German-origin citizens was also increasing due to the creation of new state institutions and the forming of city and district authorities. As a result of these changes, towards the end of the $19^{\text {th }}$ century Germans constituted already around one-fifth of the inhabitants of the Upper Silesian Industrial District, with the percentage of Germans being considerably higher in towns and in big industrial settlements than in villages, and they constituted around three-fifths in Katowice and Gliwice; in Bytom and Tarnowskie Góry, the number of Germans was close to 50 per cent of the inhabitants (MICHAŁKIEWICZ, ed., 1976: 51).

Due to the influx of Germans to towns and because of the Germanisation of education and administration, the German language was gradually becoming more common also among the Polish population of the Upper Silesia. This concerned mainly males, who, while serving in the army or during their contacts with superiors at workplace, had to use German. This situation constituted a certain threat to the Polish language and was even more dangerous due to the fact that the knowledge of the German language in Silesia was the prerequisite of social promotion and of moving to a hierarchically higher class. In all areas there were certain cultural consequences connected with social promotion. One of them was the necessity to acquire a language of a social group to which an individual moved as a consequence of promotion. In Silesia such a group was the German intelligentsia, so its language and culture were to be acquired.

The knowledge of the literary Polish was not a factor conditioning social promotion, so the Silesian intelligentsia of the Polish origin did not sever a connection with the dialect and did not feel it necessary to use the literary Polish while speaking. The language was known, but it was almost exclusively a written language, or - to be exact - a printed language, because in manuscripts not meant for printing forms characteristic of a spoken language were employed, and in Silesia the dialect performed this function.

The general Polish language was employed as a literary tool by publicists, writers, publishers, editors, and by some Catholic priests. It was the language of popular literature, songs, prayer books, sermons, magazines, and course books for learning Polish. Beyond the circle of the so-called creative intelligentsia it was known passively, but it was not 
spoken. The Silesian dialect was used in families and among neighbours, whereas German was employed in official contacts.

All this created a specific language situation in the Silesia of the second half of the $19^{\text {th }}$ century based on the opposition spoken language versus the language of Polish printed terts, which corresponded with the opposition the Silesian dialect versus the literary Polish language. Social differences played a secondary role, and even though they influenced the degree of saturation of the colloquial language with dialectic variants and German loan-words, this did not lead (in the Upper Silesia in the $19^{\text {th }}$ century) to the emergence of a separate type of language, dubbed by Antoni Furdal as a "civilised' spoken language" (FURDAL, 1973: 15). Very few representatives of the Silesian intelligentsia preserved in their speech most of phonetic dialectal features, but they appeared in their utterances and in teuts not meant for print less consistently than in the language of craftsmen and labourers.

At that time in the Upper Silesia there were no significant differences between the speech of town dwellers and of villagers. The phonological and inflectional system of the urban population, particularly of the inhabitants of small towns and industrial settlements, was close to the system of folk dialects. There were clear differences only in vocabulary, ones determined by the stronger impact of German on the inhabitants of towns and settlements rather than on rural populations. In the Upper Silesian Industrial District, the impact of the unified general Polish was weak and one-sided. Due to the lack of Polish schools and a strong group of the Polish intelligentsia, people were becoming familiar with this language solely through printed terts, especially the press and popular publications of the local typographic enterprises.

In that situation, the main opponent of German was the Silesian dialect. This fact strengthened the position of the latter in all social groups and caused the social differentiation of the language of those inhabiting the Upper Silesian Industrial District to be based not so much on a different quality of the language system components, but rather on the higher or lower degree of language variability, something showing in the frequency of dialectal forms and the consistency of their usage. In its purest form, the dialect featured in the countryside. Town dwellers were using the dialect in direct individual and local contacts, whereas in writing they were mixing dialectal forms with those present in general Polish, and the degree to which texts were saturated with dialectal elements was dependent on the writers' education and on the knowledge of the language norms of general Polish. Dialectal forms are thus employed more consistently in craftsmen's notes than in parish records written by priests.

Such conclusions can be drawn while analysing the language of Powieści ludu polskiego na Śląsku, written down by Lucjan Malinowski in $1869,{ }^{2}$ of the guild books from Woźniki,

${ }^{2}$ L. MAlinowskı, 1901: Powieści ludu polskiego na Śląsku. "MAAE” V. The terts from the following places were taken into account: Dzierżno, Michałkowice, Piekary, Radzionków, and Szobieszowice. 
Toszek, and Sośnicowice, embracing the years 1850 to $1900,{ }^{3}$ and of the parish archives from Bogucice, Katowice, and Lipiny. ${ }^{4}$

The following dialectal features of the Bytom and Gliwice regions abound in the folk novels from Silesia written down by Malinowskis:

1) the narrow articulation of the tense vowels $a, e$, which continue the old long vowels, and the positional narrowing of vowels $a$, $e$ before nasal consonants, e.g. jo (Mich: 166), Jonek (Mich: 174), móm (Radz: 184), bidny (Radz: 184), chlip (Mich: 166), kobita (Piek: 182), śnig (Mich: 167), symrańe (Mich: 172), tyn (Mich: 172), dumu (Radz: 189), kumory (Szob: 160), uni (Mich: 166);

2) the pronunciation of $-e$ in the rhyme as -a: ida (Mich: 171), ńimoga (Mich: 174), znaleza (Szab: 160), po ta cápka (Mich: 169), na ta koza (Radz: 186), bez ta řečka (Szob: 162), na skarga (Piek: 181), v sobota (Mich: 170), na śćana (Szob: 163);

3) the bi-phonemic realisation of $-a$ in the rhyme: bédom (Mich: 167), dajom (Szob: 160), potańcujom (Szob: 160), ze suchom laskom (Szob: 160), z ućechóm (Mich: 173), ze sobóm (Mich: 169), s tobóm (Mich: 172);

4) the disappearance of nasality or the transfer of nasality to the following consonant in verb forms containing -ąt, -ęt-, -ęl-, e.g. vyćagnoŭ (Dzier: 158) \| vyćóngnón (Radz: 186), vźón (Mich: 167), staneli (Mich: 175) ॥ vźeni (Mich: 168);

5) the change: it, ył> óu \| uux: buu (Mich: 174), chodźuu (Mich: 166), piznóu (Szob: 162), rob'óu (Mich: 166), postav'uu (Szob: 163), znośuu (Mich: 174);

6) the change et>oú přyšou (Szob: 161), šouech (Szob: 163), pošou (Dzier: 157), vyšouech (Szob: 162);

7) a frequent occurrence of movable $e$ in prepositions we, ze: ve smutku (Mich: 167), ve Śląsku (Mich: 168), ve v'ezy (Piek: 180), ze synem (Mich: 172), ze zav'iści (Mich: 170), ze žónom (Mich: 169);

8) mazuration': cego (Mich: 166), insych (Radz: 184), jesce (Mich: 167), jus (Radz: 186), pytás (Mich: 166), rocek (Radz: 185), usystko (Piek: 182), zyd \| žyd (Dzier: 158);

9) the simplification and transformation of consonant clusters: nimók (Piek: 183), podrus (Szob: 160), ucik (Piek: 180), garǔo (Dzier: 158), jármak (Radz: 184), pirsy (Mich: 168), chto (Mich: 174), śternaśće (Mich: 168), postřodku (Radz: 185);

${ }^{3}$ The guild books of Woźniki are to be found in Biblioteka Śląska [Silesian Library] in Katowice, under the following file reference numbers: 452/II, 453/II, 454/I. A detailed description of the books is provided by M.T. MıснаlewskA, 1966: Woźnickie księgi cechowe w zbiorach Biblioteki Śląskiej. “Biuletyn Informacyjny Biblioteki Śląskiej” 11 (4), pp. 219-227. The guild books from Toszek and Sośnicowice are deposited in the Archive in Gliwice. The terts from the second half of the $19^{\text {th }}$ century were used, and they are contained in the following books: G II 13/1, G II 13/2, G II 11/4, G II 11/5, G II 11/6.

${ }^{4}$ These are predominantly books of banns and of parish notices, kept in the archives of the Parishes of Bogucice and Lipiny, and in the Parish of the Immaculate Conception of the Virgin Mary in Katowice.

${ }^{5}$ I provide each example with the abbreviation of the place and with the page number in the collection created by Malinowski. The spelling preserves all graphic features of the source.

${ }^{6}$ Consistent mazuration occurs in texts from Michałkowice, Piekary, and Radzionków. In a story from Dzierżno mazuration occurs inconsistently, and in Szobieszowice it is not present. 
10) the $-e$ ending in the genitive of the singular of soft-thematic feminine nouns ending with -'a, e.g. skošule (Szob: 163), do piunice (Mich: 169), do skřyńe (Piek: 182), ze šyje (Szob: 161), do źemé (Dzier: 158);

11) pronominal forms: jeji (Mich: 169), jeich (Mich: 172);

12) past-tense forms with aorist -ch, e.g. alech já ńe kuṕuŭ (Szob: 162), staǔech (Szob: 161), vlázech (Mich: 175), ńe moglichmy (Piek: 180), tochmy śe pytali (Mich: 168), přyslichmy (Szob: 162).

As concerns lenical dialectisms, the following are worthy of attention: hnet (Polish wnet - "soon"; Mich: 166), kapsa (kieszeń - "pocket"; Szob: 162), máno (imię - "name"; Dzier: 167), ḿech (worek - "sack"; Piek: 183), ošydzić (oszukać - "to cheat”; Mich: 174), piznóŭ (uderzył - "he hit"; Szob: 162), pozór (uwaga - "attention"; Mich: 169), ruby (gruby - "fat"; Szob: 163), řądzić (mówić - “to speak”; Radz: 184), śodlak (wieśniak - "peasant”; Mich: 171), vćepnać (wrzucić - "to throw in"; Mich: 169), vońačka (bukiet - "bouquet”; Szob: 160).

A similar language was used by craftsmen in small Upper Silesian towns. In the preserved guild books from Woźniki, Toszek, and Sośnicowice, one can find almost all dialect features noticed by Malinowski, which are:

1) the narrow articulation of the tense vowels a, e: dlo (453/II: 9), kacmorz (G II 11/5: 5), mo (G II/6: 63), oddo (G II 11/5: 26), teros (453/II: 14), prziodzyf (G II 11/5: 3), szewieckigo (G II 11/6: 55), tysz (453/II: 34);

2) the narrowing of $e$ before nasal consonants: dłuzyn (G II 13/1: 46), piniądze (G II 11/5: 20), swobodzynio (G II 11/5: 46), tyn uczyń (452/II: 13), wylezynie (452/II: 19);

3) the pronunciation of $-e$ in the rhyme as $-a$, which is typical of Silesia: za bawetna (453/II: 23), bez ta nauka (G II 11/5: 3), robić proba (G II 11/6: 15), za słusba (453/II: 16);

4) the bi-phonemic realisation of $-q$ in the rhyme: $z$ matkom (G II 11/5: 3), swoiom rynkom (G II 11/5: 91), przed commisiiom (453/II: 6u), podpisuiom (G II 11/5: 19), zostanom (G II 11/5: 89);

5) the forms: napoczon (G II 11/5: 19), prziion (452/II: 1u), wzieno się (G II 11/4: 41);

6) the change of $i(y)$ before + into a back-series vowel: bot (G II 11/5: 9), płacioł (G II 11/5: 3), robiot (G II 11/5: 17), uczot (G II 11/5: 63), wstapyot (G II 13/1: 50v);

7) the occurrence of $i$ after rz: ktorzi (G II 11/5: 17), przitym (G II 13/1: 46), prziięty (G II 13/1: 46), przinalezy (452/II: 6), trzi (454/I: 29v);

8) mazuration 7 : nasego (454/I: 44), naucki (452/II: 18), przisłego (452/II: 5), stycnia (452/ II: 16v), ucnia (452/II: 16v);

9) the simplification of consonant clusters: garcarskiey (454/I: 31), kaczmorza (G II 11/5: 27), modsych (454/I: 18), pierszy (G II 13/2: 24v), przinios (G II 11/5: 25);

10) the $-e$ ending in noun forms: od Kommisyje (453/II: 7), od konwisyje (G II 11/6: 57), zastempce (G II 11/6: 39);

11) the pronominal form ieich (G II 11/4: 60);

12) the past-tense form with the -chmy ending: cochmy byli (G II 11/4: 48), cochmy zrobieli (G II 11/4: 43).

Some of the dialectal features mentioned above can also be found in parish records written by priests, who were the representatives of the Silesian intelligentsia. In these

${ }^{7}$ All presented examples come from the books of Woźniki. 
manuscripts there are occasional words and inflectional forms with tense $a$ or $e$ which have a dialectal character to them, e.g. ${ }^{8}$ godka (Bog, 1898), kowol (Bog, 1858), piekorz (Bog, 1862), dopomogajcie (Lip, 1900), wilijo (Bog, 1881), mularskigo (Lip, 1891), odśpiwa (Bog, 1878), sprzyczki (Bog, 1897), tysz (Bog, 1863). The dialectal features which are particularly persistent are the following: the narrowing of $e$ before nasal consonants, e.g. oświadczynie (Kat, 1891), stowarzyszyń (Lip, 1896), Szczepanym (Lip, 1894), tydzin (Bog, 1883), tyn (Bog, 1878); the occurrence of $i$ after $r z$, e.g. chorzi (Bog, 1893), przi (Kat, 1891), trzimana (Bog, 1873); prepositions we, ze used together with the words starting with a single consonant, e.g. we familiach (Lip, 1894), we waszych piecach (Lip, 1894), ze Solca (Kat, 1883), ze Sosnowca (Kat, 1882), ze zarzadu (Lip, 1896). Sporadically, there appear examples of the dialectal realisation of nasal vowels in the rhyme, e.g. na Godula (Lip, 1894), we środa (Lip, 1894), byndom (Bog, 1888). Influenced by consonants $l, t$, high vowels lower their articulation, hence the forms: czynieł (Bog, 1863), kielka (Bog, 1885), rozporzadzieła (Bog, 1874), wychodzieło (Lip, 1894). As to inflectional dialectisms, in this group of terts there was only one ending attested, namely the $-e$ ending in the genitive of the singular of softthematic feminine nouns, e.g. z Leśnice (Bog, 1874), z muflarnie (Lip, 1896), ze skarbnice (Lip, 1894). The authors of parish records also make use of lexical dialectisms, e.g. gbur (Polish wieśniak - "peasant"; Lip, 1883), grubelak (prostak - "simpleton"; Lip, 1896), maszyniok (maszynista - "train driver"; Bog, 1892), młodziak (młodzieniec - "young man”; Lip, 1894), przyleżytość (sposobność - "ownership, membership”; Bog, 1895), święcelniki (poświęcone potrawy wielkanocne - "blessed food for Easter"; Lip, 1894), szydzić (oszukiwać - "to cheat"; Lip, 1896).

A detailed analysis of parish records reveals that these are the terts characterised by a mixed linguistic code, namely the literary and the dialectal. The knowledge of general Polish manifests itself in the inconsistent usage of the dialect forms and the avoidance of the most evident dialectisms. A strong connection with the dialect is revealed in the dialectal features being present in all components of the language system. This leads to considerable variability of terts and to code-mining. This mixed language code was employed in the case of parish records at the level of local contacts in terts of a restricted range. The choice of the dialectal or general-Polish variants of language elements was determined by such factors as showing consideration for recipients of the texts and the purpose and function of these terts. Banns and parish notices were indeed meant for parishioners speaking the dialect, but they were read out at services, services during which general Polish played the role of the auniliary language in the Upper Silesia. ${ }^{9} \mathrm{By}$ this can be accounted for the tendency, visible in parish records, to use the literary language. The written form of communication was of importance as well. If there were still so many various dialectisms making their way to parish records, it is legitimate to claim that local priests, like other representatives of the Silesian intelligentsia, were employing the dialect on everyday basis in direct contacts with parishioners, a dialect which for most of them was the primary language code.

${ }^{8}$ Next to the example, I put the abbreviation of a place and the year when the inscription was made, because the parish records have no file reference numbers.

${ }^{9}$ Cf. “Zuiastun Górnoszlązki.” Vol. 1. Piekary 1868, p. 357. 
Apart from the information about the language system of the Silesian intelligentsia in the $19^{\text {th }}$ century, parish archives - and especially books of banns - provide an abundance of valuable material for the research on the influence of the German language on the language of Upper Silesian industrial settlements and on social differentiation of the Upper Silesian dialect. It was mainly vocabulary that underwent the process of differentiation, vocabulary enriched in industrial centres with the names of new professions, technical appliances, social organisations, and state institutions. These were mostly words of German origin which, as a result of phonetic and morphological adaptation, were subject to various transformations. In this way the following names of professions came into being: blędziorz (Lip, 1895), eisenbaniok (Bog, 1858), muflorz (Bog, 1871), oberhajer (Bog, 1895), polir (Bog, 1883), pudlerz (Kat, 1886), wachtorz (Kat, 1886), werczan (Kat, 1899), and the names of industrial plants, institutions, offices, and associations, e.g. na Zuzannagrubie (Bog, 1890), Knapszaft (Bog, 1896), Sparkassa (Bog, 1898), do Spielschuly (Bog, 1898), ze Standesamtu (Lip, 1895), ze szlafhauzow (Lip, 1894), z walcwerku (Lip, 1896). At the turn of the $19^{\text {th }}$ century, numerous lexical Germanisms present in the speech of the inhabitants of towns and industrial settlements became a factor revealing a variety in the up-to-that-moment homogenous dialect as well as a factor differentiating the spoken language of the Silesian urban agglomeration form the dialect of the rural population, a dialect with which it still had in common phonological and inflectional features, and the basic vocabulary range.

The type of the colloquial Upper Silesian language described above, which was poorly differentiated in social terms due to the lack of a Polish model group whose spoken language would constitute a model to be followed by socially promoted individuals, is clearly contrasted with the language of Upper Silesian printed terts, published in the second half of the $19^{\text {th }}$ century in Bytom, Mikołów, Gliwice, Piekary, and Królewska Huta. These were predominantly stories, propaganda leaflets, song books, prayer books, calendars, and the magazines meant for the local Silesian population, but written in the general-Polish literary language in the average style which was comprehensible for the uneducated recipient. The contemporaries were already aware of the difference between the folk language and the language of books. This can be demonstrated by the deliberations, published in "Zwiastun Górnoszlązki," on the topic of what type of language should be taught in Silesian schools, which are worth quoting here:

Lecz którego trzeba uczyć w szkołach naszych języka polskiego: czystego czy gminnego (ludowego)? Niech na to odpowiadają książki szkolne i kościelne pisane przecież w języku czystym, nazwanym ztąd księgowym czyli książkowym [...]. Szlązacy bowiem we wszystkich książkach swoich używają tylko czystego języka polskiego.

(So which type of the Polish language should be taught in our schools: pure or communal (folk)? Let this question be answered by school and church books indeed written in the pure language, for this reason called the language of books [...]. Because Silesians in all their books use only pure Polish.)

Zw: 357

The dialectal phonetic feature that was most difficult to avoid was the narrowing of the vowel $e$ before nasal consonants, a feature common in Silesia, attested by several 
examples in the excerpted publications ${ }^{10}$ : Cichymu (Kal: 85), chorymu (Kal: 101), Jedynymu (Śp: 15), którymu (Kal: 117), macierzystymu (Psz: 180), naczelnymu (Psz: 4), nowymu (Psz: 15), podejrzałymu (Psz: 271), słabszymu (Psz: 180), starymu (Psz: 174), sztucznymu (Psz: 174), świętymu (Zw: 413), doświadczynia (Kal: 87), pszynicy (Por: 29), dworym (Kal: 22), słowym (Kal: 87), tyn (Hel: 15).

The authors and printers also had some difficulty choosing the correct form of the prepositions $w\|w e, z\| z e$, which is easily understood in the area characterised by the pronunciation we wodzie, ze sokiem (cf. KLEMENSIEWICzównA, 1950: 196). Thus, alongside the regional forms we walce (Mem: 85), we wojnie (Kal: 22), we Warszawie (Ks: 18), we wieczności (Mem: 13), we wierze (Mem: 11), we więzieniu (Kal: 79), we wojsku (Ks: 17), ze sercem (Kal: 72), ze szafy (Kal: 102), ze zasady (Ks: 25), ze rząem (Ks: 7), there appear hypercorrect forms: $w$ wspólnym (Hus: 60), w wszystkich (Szw: 2), z smutkiem (Szw: 97), z swej (Szw: 110), z śpiewem (Hus: 60), z współczuciem (Hus: 8), z wzgardą (Kal: 76).

Apart from the aforementioned regionalisms, sporadic examples also reflect the dialectal pronunciation of nasal vowels, as in pokażom (Kal: 122), słynyła (Mem: 18), zgarnył (Kal: 103), and simplifications of consonant groups, frequently occurring in spoken language, as in $w$ kaczmie (Kal: 68), poszed (Kal: 77).

These are solely phonetic dialectisms in the researched works, works which - save the very few exceptions - preserve the sound system of general Polish. From among the dialectal inflectional forms, the only form which was allowed in printed terts was the $-e$ ending, as in z Dziewice (Śp: 58), obietnice (Hel: 5), do studnie (Hel: 15), u szyje (Hel: 21), which are based on older literary texts.

Lenical regionalisms also appear very rarely in Upper Silesian publications. In the press, they are sometimes put in parentheses, next to general-Polish words, e.g. przy grochu, bobie (fansolach) (Por: 12), w późnej jesieni (na podzim) (Por: 12), przy koniczynie (krasikoniu) (Por: 12), krochmalu (skróbku) (Por: 11), pali się (gore) (Por: 10), paszy (futra) (Por: 13), pożary (wygorania) (Por: 16), rzepaku (rapsu) (Por: 12), serwatki (kapatki) (Por: 15), siadłego mleka (kiszki) (Por: 15). In other publications, one may sporadically encounter such dialectisms as cygaństwo (Polish oszustwo - "trickery"; Ks: 20), jeno (tylko - "only"; Kal: 73), kurzyć się (dymić się - "to smoke"; Szw: 67), miano (nazwisko - "surname"; Ks: 37), młoducha (panna młoda - "bride"; Szw: 20), niemoc (choroba - "illness"; Szw: 83), posiedziciel (właściciel - "owner"; Gór: 22), przeinaczyć (przemienić - "to transform”; Ks: 15), przykopa (rów - "ditch"; Ks: 4), siodłak (wieśniak - "peasant”; Szw: 78), smyczyć się (włóczyć się - "to wander"; Szw: 64), styknąć (starczyć - "to suffice”; Kal: 95), trząchać (potrzasać "to shake"; Hist I: 45). Lexical dialectisms were employed to a larger degree by Piotr Kołodziej, the author of popular folk plays, written in general Polish and containing some dialectal features in dialogues. The protagonists of his works make use of Silesian words and expressions, e.g. a dyć (Polish przecież - "indeed"; Sąs: 6), burkot (człowiek mówiący niewyraźnie - "a person speaking indistinctly"; Ob: 19), ciarastwo (lichota - "crap"; Ob: 54), działanie (robienie masła - "butter churning"; Ob: 1), dziołcha (dziewczyna - "girl”; Ob: 18), latosi (tegoroczny - "of this year"; Sąs: 51), podsuć (podsypać - "to strew more"; Sąs: 3), pozór (uwaga - "attention"; Sąs: 26), smykać się (włóczyć się - "to roam”; Ob: 12), zberzyk

\footnotetext{
${ }^{10}$ Clarification of the title abbreviations is to be found at the end of the article.
} 
(cebrzyk - "pail"; Ob: 39); coby zaś to kosztowało (Sąs: 22), do bicia się daje (Sąs: 15), Nie damy sobie tego spodobać (Sąs: 40), Nie targaj się, jak łopałka za wozem (Sąs: 21), bez tydzień (Ob: 26), wejcie ludkowie (Sąs: 36).

Germanisms are also avoided. Apart from the acquired loan words like fara (Hist II: 30), fantować (Hist II: 88), frasunek (Hist II: 11), sfolgowanie (Hist II: 80), these are mainly official names or the ones related to industry, e.g. amtsblatu (Por: 49), do aufgebotu landwery (Por: 16), na banhofach (Por: 11), z cuchthausem (Kal: 86), galmanu i blendy (Gór: 28), $w$ fryszowniach (Gór: 22), giser (Gór: 21), gisernie (Gór: 28), hajerów (Gór: 27), hausdiner od steigermatu (Sąs: 22), do kamergeratu (Sąs: 22), knapszaft (Gór: 30), na pocztamtach (Zw: 366), szmelcernia (Gór: 18), szmelcowanie (Gór: 15), sztajgrowie (Gór: 26).

Introducing these words into publications programmatically avoiding German loan words testifies to their wide dissemination and to the lack of their Polish equivalents. As to the occurrence of Polish and German names, the Polish words were prioritised, and sometimes they were followed by a parenthesised German equivalent, e.g. podróż koleja żelazna (na eisenbanie) (Por: 27), w Tygodniku Powiatowym (kreisblacie) (Por: 16), przy dzierżawach wieczystych (erbpacht) (Por: 18), wozy parowe (lokomotywy) (Por: 11), para (dampf) (Zw: 349), pozór (Schein) (Zw: 357), rękojmia (Buirge) (Zw: 366), zdrój (Quell) (Zw: 366).

The deviations from the general Polish norm quoted above occur in Upper Silesian printed texts from the second half of the $19^{\text {th }}$ century as rare exceptions. The writers, editors, and publishers who were active at that time in the Upper Silesia were consciously striving to eliminate dialectisms and Germanisms from the written language. As concerns the phonetic and morphological systems, they achieved this goal to a high degree, whereas in the area of lexis it was difficult to completely give up on widespread words and enpressions, and especially German technical and administrative terms which had no Polish equivalents in Silesia. A mostly successful attempt to break free from German influences (lasting for centuries and still current or even growing) points to a considerable engagement of a small group of the Silesian creative intelligentsia in the fight of preserving the Polish language in the Upper Silesia in its pure, uncontaminated form. Care of the Polish language manifested itself both in its painstaking cultivation and the dissemination via cheap and accessible publications, and in appeals directed towards the Silesian population and teachers.

In the first volume of "Zwiastun Górnoszlązki," Odezwa do Szanownych Panów Nauczycieli przy górnoszlazkich szkołach [The Appeal to the Estimable Gentlemen Teachers by Upper Silesian Schools] was published; in this appeal, the teachers were exhorted to perfect their pronunciation by means of reading Polish books and magazines and to teach correct Polish to children. This was motivated as follows:

Radzcy szkolni żądają w szkołach polskich mówienia, czytania i pisania w języku polskim poprawnym, a książki polskie rozporządzeniem Zwierzchności szkolnej $w$ szkołach zaprowadzane, są pisane $w$ języku czystym również i katechizm, historye biblijne i śpiewnik. Aby zrozumieć treść tychże książek, śpiew kościelny i kazanie, powinny się dzieci uczyć języka czystego; powinien więc nauczyciel sam go znać i z dziećmi tylko nim mówić. 
(School council members demand that in Polish schools speaking, reading, and writing be in correct Polish, and that Polish books, by virtue of the decree of the school Authorities, be introduced. In the pure language there are also written a catechism, biblical stories, and a song book. In order to understand the content of these books, church singing, and a sermon, children should learn the pure language; thus, the teacher should know this language himself and speak with children using this language only.)

Zw: 350

When the Polish language was removed form schools, an appeal to parents was made:

Uczcie zawczasu dzieci, że są Polakami [...]. Uczcie ich języka polskiego i uczcie ich kochać ten język [...]. Nie pozwólcie w domu używać innego języka! Dajcie jak najprędzej dzieciom $w$ ręce książki i pisma polskie. Uczcie dzieci pieśni polskich kościelnych i świeckich. Bądźcie sami przykładem miłości swego rodu i swego języka.

(Teach your children very early that they are Poles [...]. Teach the Polish language to them and teach them to love this language [...]. Do not allow them to use a different language at home! As soon as possible put Polish books and magazines in the hands of your children. Teach Polish songs to children, both church and secular ones. Yourselves set the example of love for your kin and for your language.)

Thanks to the efforts and work of writers and national activists, and owing to the consistency of the Silesian people, despite the intrusion of German and various methods of Germanisation, what was preserved in the Upper Silesia was not only the local dialect, but also partly at least the passive knowledge of general Polish and the awareness of the bond that ties these two variations of language. Of course, the dialect had a stronger position as the basic means of language communication and as a direct opponent of German, but also as the symbol of nationality and an important component of the Silesian regional attachment. All this can explain high social prestige of the Silesian dialect and an exceptionally strong attachment to dialectal language forms in all social environments. The remnants of this historical conditioning are both considerable saturation of the language of Upper Silesian city dwellers with dialectal elements and, characteristic of Silesia, equality in local contacts, especially of individual dialectal forms with these of general Polish. The consequence of the above is the dialectal phonological and literary dual-system basis, not only of the middle-aged generation of Upper Silesians, but also of the youngest generation (cf. LuBAś, 1979: 189-190).

\section{Clarification of abbreviations ${ }^{11}$}

Bog - Bogucice.

Dzier - Dzierżno.

${ }^{11}$ The titles of the sources are given in the original spelling. 
Gór - Historya górnictwa na Górnym Szląsku. Bytom 1892.

Hel - Historya o cierpliwej Helenie. Mikołów 1874.

Hist - Historya Bytomia i Piekar. Bytom 1891.

Hus - MıаRкA K.: Husyci na Górnym Śląsku. Mikołów.

Kal - Kalendarz Maryański. Vol. 2. Mikołów 1885.

Kat - Katowice.

Ks - Książeczki dla katolickiego ludu polskiego. Bytom 1896.

Lip - Lipiny.

Mem - Szafranek J.: Memento mori. Bytom 1859.

Mich - Michałkowice.

Ob - Kotodziej P.: Obieżysasi. Bytom 1895.

Piek - Piekary.

Por - "Poradnik dla Ludu Górno-ślązkiego." Vol. 1. Bytom 1851.

Psz - Lompa J.: Nowe udoskonalone pszczolnictwo ks. plebana Dzierżona. Piekary 1852.

Radz - Radzionków.

Sąs - Kotodzıej P.: Sąsiedzi. Bytom 1892.

Szob - Szobiszowice.

Szw - Mıаrка K.: Szwedzi w Lędzinach. Mikołów.

Śp - Dostateczny śpiewnik kościelny i domowy. Piekary 1850.

Zw - “Zwiastun Górnoszlązki." Vol. 1. Piekary 1868.

\section{References}

Furdal A., 1973: Klasyfikacja odmian współczesnego języka polskiego. Wrocław.

Klemensiewiczówna I., 1950: Czy wolno nam mówić we wodzie ze sokiem? “Język Polski” 30 (5), pp. 193-203.

LuBAś W., 1979: Wariantywność języków miejskich. In: Społeczne uwarunkowania współczesnej polszczyzny. Szkice socjolingwistyczne. Kraków, pp. 169-195.

Malınowskı L., 1901: Powieści ludu polskiego na Śląsku. “MAAE” V.

MichalewsKA M.T., 1966: Woźnickie księgi cechowe w zbiorach Biblioteki Śląskiej. "Biuletyn Informacyjny Biblioteki Śląskiej" 11 (4), pp. 219-227.

MichAtKiEWicz S., ed., 1970: Historia Śląska. Vol. 2. Wrocław.

MichatKiewicz S., ed., 1976: Historia Śląska. Vol. 3. Wrocław.

Alina Kowalska

The Social Differentiation of the Polish Language of the Upper Silesia in the Second Half of the $19^{\text {th }}$ Century

Sum mary

The industrialisation of the Upper Silesia, development of new towns and industrial settlements, and various methods of Germanisation applied to the society caused changes in the ethnic structure of this region and strengthened the position of the German language there. The major opponent to 
German was the Silesian dialect used both by town dwellers and countrymen in their families and neighbouring communities, and also by the scarce representatives of the Silesian intelligentsia.

The differences between the village slang and that of the people living in towns were mainly connected with vocabulary which, especially in the industrious centres, was exposed to strong German influence. The common language of the intelligentsia was that of a miked character; it included many phonetic dialectical characteristics, even though irregularly used ones. The general Polish language was known passively, but not used. It was the language of the prayer books, songs, sermons, calendars, and magazines printed by the local publishing houses. All of these factors created a specific linguistic situation which was based on the following issue: in the Silesia of the second half of the $19^{\text {th }}$ century, the opposition of spoken language versus the language of printed terts equalled the opposition of dialect versus the literary Polish language. 